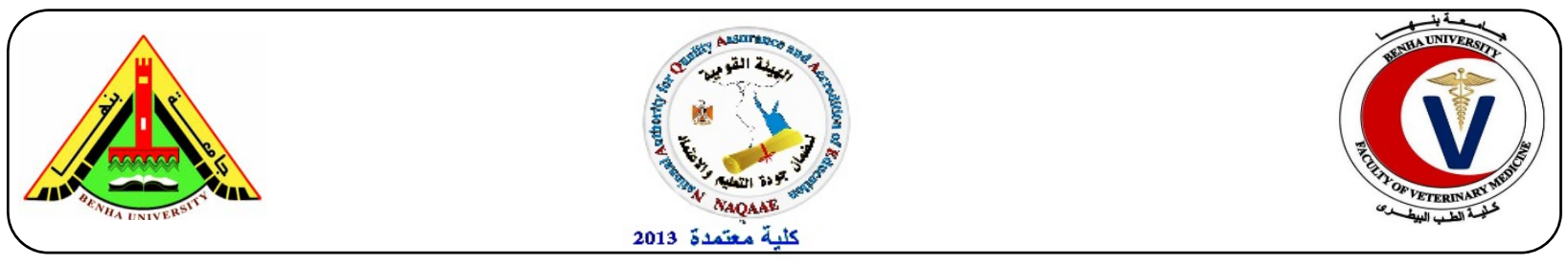

\title{
Detection of $C$. perfringens toxins in vacuum packaged meat products by using polymerase chain reaction.
}

\author{
Hemmat M. Ibrahim ${ }^{1}$, Reham A. Amin', Mohammed A. El-Shater' ${ }^{2}$ Marwa M. Mohammed ${ }^{3}$ \\ ${ }^{1}$ Department of Food Control, Faculty of Veterinary Medicine, Benha University. ${ }^{2}$ Animal Health \\ Research Institute, Dokki, Giza,. ${ }^{3}$ Animal Health Research Institute, Benha.
}

\begin{abstract}
A B S T R A C T
A total of 100 random samples of vacuum packaged meat products represented by sausage, luncheon, frunkfurter and salami (25 of each) were collected from different supermarkets in Cairo, Giza and Kalyobia governments. The prevalence of total anaerobes was $84 \%$ with account ranged between $<10$ and 5.38 with a mean $3.58 \pm 0.36$ for sausage, $56 \%$ with account ranged between $<10$ and 3.92 with a mean value $1.76 \pm 0.33$ for salami total anaerobes in and $60 \%$ with account ranged between $<10$ and 5.73 with a mean $2.55 \pm 0.44$ for luncheon. The incidence of Clostridia perfringens isolated from the examined samples of vacuum packaged salami, sausage, luncheon and frunkfurter was $44 \%, 80 \%, 32 \%$ and $0 \%$ respectively. The enterotoxins of Clostridia perfringens isolated from the examined meat products by traditional methods were type A and type C. Agarose gel electrophoresis of multiplex PCR of specific primers for characterization of enterotoxins (A, C \& D) of C. perfringens indicated that sausage had enterotoxin type $\mathrm{A}$ and enterotoxin type $\mathrm{C}$, luncheon had enterotoxin type $\mathrm{A}$, enterotoxin type $\mathrm{C}$ and enterotoxin $\mathrm{D}$, however salami had enterotoxin type A and type D.
\end{abstract}

Keywords: Vacuum packed, Meat products, Enterotoxins, PCR.

(http://www.bvmj.bu.edu.eg)

conference issue

(BVMJ-28(2): 67-73, 2015)

\section{INTRODUCTION}

I

n Egypt, there is an increase demand for both ready to cook and ready to eat meat products due to the relative large numbers of women employed outside their homes and consequently lack of their time available for preparation of family meals. Processed meat products may affect the public health due to their contamination with spoilage microorganisms which are responsible for objectionable changes as well as the presence of pathogenic organisms which may leads to either food infection or food intoxication (libby , 1975; Hanninen , 1980 and FAO /WHO, 1983). Clostridia are the most frequently anaerobic organism, which contaminates the food; they are able to survive the relatively high temperature by production of their resistant spores (Branes, 1985).

C. perfringens is one of this groups which have great effect on the human health as food poisoning organism. C. perfringens is being responsible for food poisoning; also cause a number of human diseases ranging from necrotic enteritis to wound infections and life threatening gas gangrene. Such pathogenicity is associated with the lethal extra cellular toxins which have defined as enzyme activity as collagenase, hyalauronidase and deoxyribonuclease (Norris and pettipher 1987). Usually, the poor quality raw materials of the meat products as well as the lack of necessary facilities to hold food within the 
recommended temperature, thus the existing microorganisms reach high levels sufficient to produce food borne diseases (primo et al., 1993). C. perfringens organisms were responsible for $7.9 \%$ of 62 food poisoning outbreaks affecting 6093 persons in USA in the period between 19711980 due to the consumption of meat and its products contaminated with such serious organisms (ICMSF, 1996). Many of pathogenic Clostridial species are normal inhabitant of the intestinal tract of animal and man as well as birds. The organisms can survive indefinitely in the environment (Brynestad and Granum, 2002). Strains of C.perfringens were divided into five toxicological types (A, B, C, D and E) on the basis of four major lethal toxins (alpha, beta, epsilon and iota). Alpha toxin, which is common in all types, exhibits an enzymatic activity and the protein is known to have a lethal haemolytic and necrotic activities. Only type A strain is responsible for food poisoning and type $\mathrm{C}$ (human type) has been implicated as the cause of a more severe form of gastroenteritis with a high mortality rate known as enteritis necroticans (Hobbs et al., 1982 and Labbe, 1988). Moreover, C.perfringens is considered as one of the major spoilage microorganism of meat and meat products. Considering all these hazards, the current study was applied to investigate the contamination of vacuum packaged meat products with anaerobic bacteria through the following topics: enumeration of total anaerobic count in vacuum packaged meat products. Isolation and identification of $C$. perfringens using conventional method. Detection of $C$. perfringens toxin by using lab animal. Rapid detection of $C$. perfringens toxins by multiplex polymerase chain reaction (PCR).

\section{MATERIAL AND METHODS}

\subsection{Collection of samples}

A total of 100 random samples of vacuum packaged meat products were collected from different supermarkets in Cairo, Giza and Kalyobia governorates. The collected samples were represented by sausage, luncheon frunkfurter and salami (25 of each). These samples were obtained in their intact original package and preserved in an ice box then transferred to the laboratory under complete aseptic condition without undue delay and examined as rapidly as possible.

\subsection{Bacteriological examination}

Enumeration of the examined microorganisms. Total anaerobic bacterial count (Roberts et al., 1995): Isolation and Idintification of Clostridium perfringens (MacFaddin, 1980 and Cato et al., 1986). Demonstration of Clostridium perfringens toxin by dermo-necrotic test (Sterne and Bathy, 1975).

\section{3. preparation of toxin and their treatment (Bullen,1952)}

Five $\mathrm{ml}$ of 24 hours cooked meat media suspected cultures of Clostridium perfringens toxigenic strain were inoculated into $50 \mathrm{ml}$ of toxin production medium containing $60 \%$ glucose, and then incubated in water bath at $37^{\circ} \mathrm{C}$ for 5 hours. During the period of incubation, $\mathrm{pH}$ was adjusted each hour to 7.2, after 5 hours incubation, half of culture was symphonized and centrifuged at $3000 \mathrm{rpm}$ for 20 minutes. The clear supernatant fluid was then divided into 4 portions: The first portion $(0.3 \mathrm{ml})$ was added to $0.1 \mathrm{ml}$ of saline as control serum. The second portion $(0.3 \mathrm{ml})$ was neutralized with $0.1 \mathrm{ml}$ of type A diagnostic antiserum. The third portion $(0.3 \mathrm{ml})$ was neutralized with $0.1 \mathrm{ml}$ of type $\mathrm{B}$ diagnostic antiserum. The fourth portion $(0.3 \mathrm{ml})$ was neutralized with $0.1 \mathrm{ml}$ of type $\mathrm{C}$ diagnostic antiserum. The other half of the same culture was anaerobically incubated at $37^{\circ} \mathrm{C}$ for 48 hours. The $\mathrm{pH}$ (7.2) was adjusted twice daily then centrifuged as mentioned before and the supernatant was trypsinized by type $\mathrm{D}$ and type $\mathrm{E}$ diagnostic antisera in the same ratio $(3: 1)$ for toxin, antitoxin respectively.

\subsection{Application of the typing test (Oakley and Warrack, 1953)}


This test was applied on Albino Guinea pigs , with an average body weight about 350 450 grams, the animal were kept under observation for two weeks before the beginning of the experiment and the hair of the back of each side were carefully shaved and marked longitudinally onto both sides. On the right side $0.2 \mathrm{ml}$ of the 5 hours of trypsinized 48 hours supernatant of each culture was intradermal injected and the neutralized one was injected into the half side in the same manner and arrangement .the injected Guinea pigs were kept under observation for 48-72 hours to demonstrate any dermal reaction. The results were interpreted by the degree of dermonecrotic reaction and its neutralization according to Sterne and Batty (1975) as follow: Type A: toxin produced an irregular area of yellowish necrosis, lesion spread down ward (alpha toxin). Type B: toxin produces purplish yellow hemorrhagic necrosis (beta toxin). Type $\mathrm{C}$ : toxin produced a reaction which was intensively blue than that of type B Filtrate. Type D: toxin produced a circular white necrosis which was fully developed in 24Hours (epsilon toxin). Sometimes it showed a few small areas of purplish Hemorrhagic necrosis. Type E: toxin produced a reaction similar to that elicited by type $\mathrm{D}$ but with Irregular outline and more marked purplish hemorrhagic appearance (iota toxin).

\subsection{Polymerase chain reaction (PCR)}

Two or three colonies from isolates and reference strain grown on blood agar were suspended in $300 \mu 1$ distilled water, and the mixture was then incubated at $56^{\circ} \mathrm{C}$ for 30 minutes. The samples were treated with $300 \mu 1$ of TNES buffer $(20 \mathrm{mM}$ Tris pH8.0, $150 \mathrm{mM} \mathrm{NaCl}, 10 \mathrm{mM}$ EDTa, 0.2\% SDS) and proteinase $\mathrm{K} \quad(20 \mathrm{mg} / \mathrm{ml})$.After incubation at $37^{\circ} \mathrm{C}$ for $2 \mathrm{~h}$ the mixture was boiled for 10 minutes. To that suspension, same volume of phenol (saturated with TrisHCL) was added; the suspension was shaken vigorously by hand and centrifuged at $11600 \mathrm{~g}$ for 10 minutes. The upper phase was transferred into another tube and sodium acetate ( 0.1 volumes) and ethanol ( 2.5 volumes) were added. The suspension was kept at $-20^{\circ} \mathrm{C}$ for $1-5 \mathrm{~h}$ and then centrifuged at $11600 \mathrm{~g}$ for 10 minutes. The pellet was washed with 95 and $70 \%$ ethanol, each step followed by 5 min centrifugation. Finally the pellet was dried and resuspended in $50 \mu \mathrm{l}$ distilled water.The PCR was performed in a touchdown thermocycler (Hybaid) in a total reaction volume of $50 \mu 1$ containing $5 \mu \mathrm{l}$ of $10 \times$ PCR buffer $(10 \mathrm{mM}$ Tris-HCL, pH 9.0, 50mM KCL, $0.1 \%$ Trition X-100), $5 \mu 125 \mathrm{mM} \mathrm{MgCL}_{2}, 200 \mu \mathrm{M}$ of each deoxynucleotide triphosphate, $5 \mathrm{U}$ of Taq DNA polymerase, $1 \mu \mathrm{M}$ each of primers and $5 \mu 1$ of template DNA. Alpha, beta, epsilon, and iota toxin primers from Yoo et al. (1997) and enterotoxin primers from Gkiortzidis et al. (2001) were used in the multiplex PCR.

Amplification was obtained with 30 cycles following an initial denaturating step at $94^{\circ} \mathrm{C}$ for $1 \mathrm{~min}$, annealing at $55^{\circ} \mathrm{C}$ for $1 \mathrm{~min}$, and synthesis at $72^{\circ} \mathrm{C}$ for 1 minute. $10 \mu 1$ of the amplified products were electrophoresed in a $1.5 \%$ agarose gel and stained with ethidium bromide. Amplified bands were visualized and photographed under UV illumination.

\section{RESULTS}

Table (2) illustrated that the prevalence of total anaerobes was $84 \%$ with account ranged between $<10$ and 5.38 with a mean $3.58 \pm 0.36$ for sausage, $56 \%$ with account ranged between $<10$ and 3.92 with a mean value $1.76 \pm 0.33$ for salami total anaerobes in and $60 \%$ with account ranged between $<10$ and 5.73 with a mean $2.55 \pm 0.44$ for luncheon. Table (3) indicated that the incidence of Clostridia perfringens isolated from the examined samples of vacuum packaged salami, sausage, luncheon and frunkfurter was $44 \%, 80 \%, 32 \%$ and $0 \%$ respectively. Table (3) indicated that the enterotoxins of Clostridia perfringens isolated from the examined meat products by traditional methods were type A and type C. Figure (1) Agarose gel electrophoresis of multiplex PCR of specific primers for 
characterization of enterotoxins (A, C \& D) of $C$. perfringens sausage had enterotoxin type $\mathrm{A}$ and enterotoxin type $\mathrm{C}$, luncheon had enterotoxin type $\mathrm{A}$, enterotoxin type $\mathrm{C}$ and enterotoxin D. However, salami had enterotoxin type A and type D. Figure (1) the reading of multiplex PCR indicated that sausage has enterotoxin type $\mathrm{A}$ and enterotoxin type C. Luncheon has enterotoxin type $\mathrm{A}$, enterotoxin type $\mathrm{C}$ and enterotoxin D. Salami has enterotoxin type A and type D.

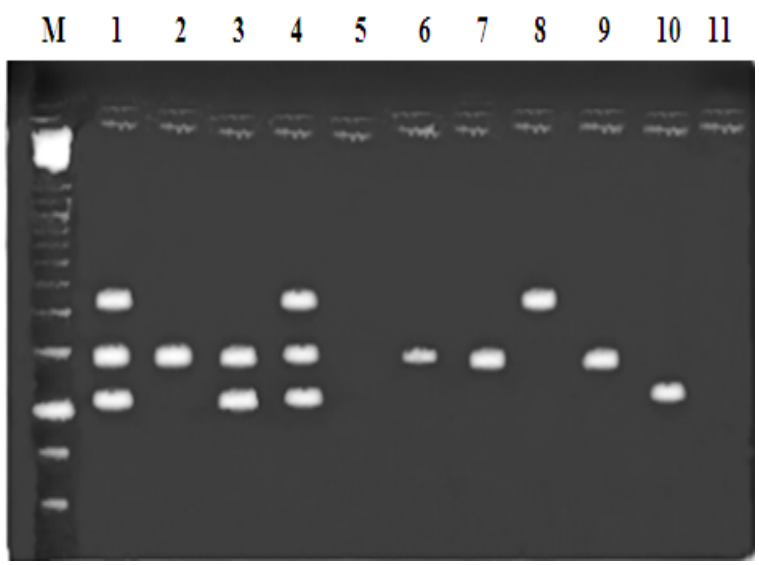

Figure (1): Agarose gel electrophoresis of multiplex PCR of specific primers for characterization of enterotoxins (A, D \& C) of C. perfringens. Lane M: $100 \mathrm{bp}$ ladder as molecular size DNA marker. Lane 1: Control positive for cpa (402 bp) gene for $C$. perfringens enterotoxin type $\mathrm{A}$, cpc $(317 \mathrm{bp})$ gene for $C$. perfringens enterotoxin type C \& cpd (541 bp) gene. Lane 11: Control negative for cpa, cpd \& cpc genes. Lanes 2, 3, 4, 6, 7 and 9: Positive samples for enterotoxin A (cpa). Lanes 3, 4 and 10: Positive samples for enterotoxin $\mathrm{C}$ ( $\mathrm{cpc})$. Lanes 4 and 8 : Positive samples for enterotoxin D (cpd). Lane 5: negative samples for enterotoxin A (cpa), enterotoxin C (cpc), enterotoxin D(cpd). N.B: Sausage samples occupied lanes 2, 3 and 4 . Luncheon samples occupied lanes 5, 6 and 7. Salami samples occupied lanes 8,9 and 10

\section{DISCUSSION}

The results in table (2) illustrated that, the prevalence of total anaerobic microorganisms isolated from vacuum packaged salami $56 \%$ with account ranged between $<10$ and 3.92 with a mean value $1.76 \pm 0.33$ that result is higher that detected by El Rays (2014) who reported that the prevalence total anaerobic microorganisms isolated in vacuum packaged salami
28\%.According to E.O.S (Egyption Organization for Standarization and Quality) \{E.S (4177/2005) for salami\} which reported that the total anaerobic count for salami must be not more than $10^{2}$ anaerobs /gm . Thus, 44\% of examined samples were accepted and 56\% of examined samples were unaccepted. The prevalence of total anaerobes for sausage was $84 \%$ with account ranged between $<10$ and 5.38 with a mean $3.58 \pm 0.36$ That result is higher than that detected by Abd ElRahman(1996) who reported that $80 \%$ of sausage samples were positive for anaerobic bacteria. According to E.O.S (Egyption Organization for Standarization and Quality ) \{E.S(3492/2005) for sausage which reported that the total anaerobic count for sausage must be not more than 100 anaerobs /gm .so in this result $16 \%$ of Table (1) Primer sequences of C. perfringens enterotoxin genes used for PCR identification system examined samples was accepted and $84 \%$ of examined samples was unaccepted. The prevalence of total anaerobes for luncheon $60 \%$ with account ranged between $<10$ and 5.73 with a mean $2.55 \pm 0.44$ That result is higher than that detected Aiedia (1995), Abd El-Rahman et al. (1996) and Abo-Zaied (1998) as Aieda (1995) detected that the mean value of luncheon samples $2.1 \times 10^{3}$ anaerobes $/ \mathrm{gm}$. Abd El-Rhman et al. (1996) detected that $50 \%$ of luncheon samples were positive for anaerobic bacteria. Abo-Zaied (1998) detected that the mean value of total anaerobic count of luncheon samples was $7.4 \times 10^{3}$ anaerobes /gm. According to E.O.S (Egyptian Organization for Standarization and Quality) \{E.S (1114/2005) for luncheon\}, which reported that the total anaerobic count for luncheon must be free from anaerobes which produce H2S. Therefore, in this result, $40 \%$ of examined samples were accepted and $60 \%$ of examined samples was unaccepted. The prevalence of total anaerobes for frunkfurter was $0 \%$ that result is lower than that detected by Zakaria 
Table (1) Primer sequences of C. perfringens enterotoxin genes used for PCR identification system

\begin{tabular}{|c|c|c|c|c|}
\hline $\begin{array}{l}\text { Target } \\
\text { enterotoxin gene }\end{array}$ & Primer & $\begin{array}{l}\text { Oligonucleotide sequence }\left(5^{\prime} \rightarrow\right. \\
\left.3^{\prime}\right)\end{array}$ & $\begin{array}{l}\text { Amplicon } \\
\text { (bp) }\end{array}$ & Reference \\
\hline \multirow[b]{2}{*}{ A } & cpa (F) & $\begin{array}{l}\text { 5' AAG ATT TGT AAG GCG } \\
\text { CTT '3 }\end{array}$ & & \multirow[b]{2}{*}{$\begin{array}{l}\text { Kalender et al. } \\
\text { (2005) }\end{array}$} \\
\hline & $\begin{array}{l}\text { cpa } \\
(\mathrm{R})\end{array}$ & $\begin{array}{l}5^{\prime} \text { ATT TCC TGA AAT CCA CTC } \\
33\end{array}$ & 402 & \\
\hline \multirow[b]{2}{*}{$\mathrm{C}$} & $\begin{array}{l}\mathrm{cpb} \\
(\mathrm{F})\end{array}$ & $\begin{array}{l}\text { 5' GCGAATA TGCT } \\
\text { GAATCATCTA '3 }\end{array}$ & \multirow[b]{2}{*}{317} & \multirow[b]{2}{*}{$\begin{array}{c}\text { Moller and } \\
\text { Ahrens (1996) }\end{array}$} \\
\hline & $\begin{array}{l}\mathrm{cpb} \\
(\mathrm{R})\end{array}$ & $\begin{array}{l}\text { 5' GCAGGAA CATTA } \\
\text { GTATATCTTC '3 }\end{array}$ & & \\
\hline \multirow[b]{2}{*}{$\mathrm{D}$} & $\begin{array}{l}\mathrm{cpx} \\
(\mathrm{F})\end{array}$ & $\begin{array}{l}\text { 5' GCGGTGATA TCC } \\
\text { ATCTATTC ' } 3\end{array}$ & \multirow[b]{2}{*}{541} & \multirow[b]{2}{*}{$\begin{array}{c}\text { Moller and } \\
\text { Ahrens (1996) }\end{array}$} \\
\hline & $\begin{array}{l}\mathrm{cpx} \\
(\mathrm{R})\end{array}$ & $\begin{array}{l}\text { 5' CCACTT } \\
\text { ACTTGTCCTACTAAC '3 }\end{array}$ & & \\
\hline
\end{tabular}

Table (2) Statistical analytical results of total anaerobic count $\left(\log _{10} \mathrm{cfu} / \mathrm{g}\right)$ in the examined meat products $(\mathrm{n}=25)$

\begin{tabular}{|c|c|c|c|c|c|c|c|c|c|c|c|}
\hline \multirow{2}{*}{$\begin{array}{c}\text { Meat } \\
\text { products }\end{array}$} & \multicolumn{2}{|c|}{$\begin{array}{l}\text { positive } \\
\text { samples }\end{array}$} & \multirow[b]{2}{*}{ Min. } & \multirow{2}{*}{ Max. } & \multirow{2}{*}{\multicolumn{2}{|c|}{$\begin{array}{c}\text { Mean } \pm \\
\text { SE }\end{array}$}} & \multirow{2}{*}{$\mathrm{PL}^{*}$} & \multicolumn{2}{|c|}{$\begin{array}{c}\text { Accepted } \\
\text { samples }\end{array}$} & \multicolumn{2}{|c|}{$\begin{array}{c}\text { Unaccepted } \\
\text { samples }\end{array}$} \\
\hline & No. & $\%$ & & & & & & No. & $\%$ & No. & $\%$ \\
\hline Salami & 14 & 56 & $<10$ & 3.92 & $\begin{array}{l}1.76 \\
0.33^{\mathrm{b}}\end{array}$ & \pm & $<10^{2}$ & 11 & 44 & 14 & 56 \\
\hline Sausage & 21 & 84 & $<10$ & 5.38 & $\begin{array}{l}3.58 \\
0.36^{\mathrm{a}}\end{array}$ & \pm & $<10^{2}$ & 4 & 16 & 21 & 84 \\
\hline Luncheon & 15 & 60 & $<10$ & 5.73 & $\begin{array}{l}2.55 \\
0.44^{b}\end{array}$ & \pm & 0 & 10 & 40 & 15 & 60 \\
\hline Frankfurter & 0.00 & 0.00 & $<10$ & 0.00 & $\begin{array}{l}0.00 \\
0.00^{\mathrm{c}}\end{array}$ & \pm & $<10^{2}$ & 25 & 100 & 0 & 0 \\
\hline
\end{tabular}

PL*: Permissible limit according to EOS (2005).

Table (3): Incidence of C. Perfringens in the examined meat products $(n=25)$

\begin{tabular}{lcc}
\hline & \multicolumn{2}{c}{ Positive Samples } \\
\cline { 2 - 3 } Meat Products & No. & $\%$ \\
\hline Salami & 11 & 44 \\
Sausage & 20 & 80 \\
Luncheon & 8 & 32 \\
Frankfurter & 0 & 0 \\
\hline
\end{tabular}

Table (4): Incidence of enterotoxins of $C$. perfringens isolated from the examined meat products by traditional method $(\mathrm{n}=25)$

\begin{tabular}{lcccc}
\hline Meat & \multicolumn{4}{c}{ Enterotoxins } \\
\cline { 2 - 5 } Products & \multicolumn{2}{c}{ A } & \multicolumn{2}{c}{ C } \\
\cline { 2 - 5 } & N0. & $\%$ & N0. & $\%$ \\
\hline Salami & 1 & 4 & 2 & 8 \\
Sausage & 5 & 20 & 1 & 4 \\
Luncheon & 1 & 4 & 1 & 4 \\
Frankfurter & 0 & 0 & 0 & 0 \\
\hline
\end{tabular}

(2009) who reported that the total anaerobes in vacuum packaged frunkfurter was $13.3 \%$. According to E.O.S (Egyption Organization for Standarization and Quality) \{E.S (3492/2005) for frunkfurter\} which reported that the total anaerobic 
count for frankfurter must be not more than 100 anaerobs /gm. So in this result 100\%of examined samples was accepted. Presence of anaerobic microorganisms in the examined samples of vacuum packaged meat products could be attributed to bad quality of raw materials and additives, insufficient heat treatment, unsatisfactory sanitation during handling, processing and storage as well as inadequate refrigeration of such food articles (ICMSF, 1996). Furthermore, the cold storage of vacuum packaged meat products decrease the growth rate of putrefactive anaerobic spore forming bacteria (Potter, 2001).

Table (3) indicated that the incidence of $C$. perfringens isolated from examined samples of vacuum packaged salami, sausage, luncheon and frunkforter was $44 \%, 80 \%, 32 \%$ and $0 \%$ respectively .According to salami this result is higher than that detected by El Rays (2014) who reported that $C$. perfringens was $12 \%$ of examined samples. According to sausage this result is lower than Guzman et al. (1990) who reported that $80.8 \%$ of examined samples were positive $C$. perfringens.

This result is higher than Abd El-Rahman et al. (1996) who isolated C. perfringens from $55 \%$ of examined samples. This result is higher than El-lawendy (1996) and Eleiwa(2003) as they isolated $C$. perfringens from $62 \%$ and $16 \%$, respectively of examined samples. According to luncheon this result is higher than that inZakaria (2009) as he isolated $C$. perfringens from $6.6 \%$ of examined vacuum packaged luncheon samples. This result is higher than that in Khater (2004) and Shaltout (1999) as they failed to detect $C$. perfringens in vacuum packaged luncheon. This result is higher than that in El -Lawendy (1996) who found that $C$. perfringens isolated from $25.53 \%$ of examined samples. This result is lower than that reported by Edris et al. (1992) and Abd El-Rahman et al. (1996) as they isolated C.perfringens from $40 \%$ and $50 \%$ of examined samples respectively. According to frunkfurter this result is lower than that reported by El Rays (2014) as she isolated C. perfringens from $16 \%$ of examined samples. In the present result, the incidence of C.perfringens in frunkfurter is lower than that result obtained by Khater (2004) which was $10 \%$ of examined samples. This result is in harmony with Venugopal et al. (1993) as they failed to detect C.perfringens from certain vacuum packaged meat products contributing this to the use vacuum in the package of these examined samples. From the public health point of view, most of these Clostridial species isolated from examined samples vacuum packaged meat products have no health hazard importance but it have a great role in the deteriorative changes of these products which rendering them unfit for human consumption (Gibbs, 1991).

Table (4) show the incidence of enterotoxins of $C$. perfringens isolated from the examined meat products by traditional methods.

This result detect the presence of enterotoxin type A and type C. which is similar to that in Granum (1990). This result differ with Saito and Funabashi (1991) as they detected toxin type A, B, C, D, E and $\mathrm{I}$ in the examined samples. Also this result differ with Cavalcanti et al., (2004) as they purified different toxin that produced by C.perfringens \{Alpha , Beta , Epsilon , Theta , Iota , Delta , Lambada and enterotoxin\}.This result differ with Fernandez et al. (2007a) as they detected 15 toxins including Alpha toxin (CPA), Beta toxin (CPB) , Epsilon-toxin (ETX) , Enterotoxin , Beta2 - toxin (CPB2) and perfringolysin.

\section{REFERENCES}

Abd El - Rahman, M. AbdAllah, W.H., Abd El - Aziz 1996. Anaerobic and aerobic aspects of bacterial contamination in frozen meat and 
meat products. Zagazig J. Pharm. Sci. 4:227.

Abo-Zaied, S.M.A. 1998.Anaerobes in meat and fish products and their ability to toxin production. Ph. D. Sc. Thesis, Fac. Vet. Med. Cairo Univ.

Aiedia, M.A.M. 1995.Quality investigation in to room kept traditional meat products in Egypt. Ph. D. Sc. Thesis, Fac. Vet. Med. Cairo Univ.

Bruce, A., Mcclane, Philip, C., Hanna and Andrew, P., wnnek. 1988. Clostridium perfringens enterotoxin Department of Microbiology, Biochemistry and Molecular Biology, University of Pittsburgh, school of medicine Pittsburgh, PA 15261, U.S.A 4:317-323.

Cavalcanti, M.H. Porto, T., Porto, A.L.F., Brandi, I.V., Linafilho, J.L., pessoa, J.A.2004.Large scale purification of Clostridium perfringens toxins. Revista Brasilia De Ciencias Farmaceuticas 40(2):15-64.

Edris, A.M., EL-Bardisy, M., Mausa. M.M. 1992. Studies on Microbial status of some markets .meat products with special reference to Clostredium perfringins Egypt J. App. Sci.7:19-30.

El -Lawendy, Hanan 1996. Occurrence of Clostridium perfringens in locally produced meat products M. V. Sc. Thesis (Meat Hygiene), Fac. Vet. Med. Moshtohour, Zagazig Univ. Banha Branch

Eleiwa, Nesreen, Z. 2003. Effect of chemical preservative on food poisoning bacteria in some locally manufactured meat products $\mathrm{PhD}$. Sc. Meat Hygiene Thesis, Fac. Vet. Med., Zagazig Univ., Benha Branch.

El-Rays, A.M.A. 2014. Aerobic and anaerobic spore formers in vacuum packaged meat products. Ph. D. Sc. Thesis, Fac. Vet. Med. Benha Univ.

Fernandez, M.M.E., Marcellino, R., Uzal, F.A. 2007a. Clostridium perfringens type A toxin production in 3 commonly used culture media. J. Vet. Diagn. Invest. 19(2):184 -186.
Gibbs, P.A. 1991. The incidence of Clostridia in poultry carcasses and poultry processing plants. B.P.S. 12:101-110.

Granum, P.E. 1990. C. perfringens toxins involved in food poisoning Inter. J. food MiCrobiol., 10:102-112.

Khater, D.F. 2004. Studies on microbial toxins in some vacuum-packed meat products. PHD. V. Sc. Thesis (Meat Hygiene), Fac. Vet. Med., Zagazig Univ. (Benha branch).

Shaltout, F. A. 1999. Anaerobic bacteria in vacuum packaged meat products. Benha Vet. Med .J, 10(1):1-10.

Venugopal, R. J., Inghram, S.C., Mecurdy, A.R., Jones, G. A.1993. Anaerobic microbiology of fresh beef packaged under modified atmosphere or vacuum .J. Food Sci.:935.

Zakaria, I. M. 2009. Clostridial species and related anaerobic organisms in vacuum packaged meat products with special reference to their shelf life. $\mathrm{Ph}$. D. Sc. Thesis (Meat Hygiene), Benha Univ. 